\title{
The Suffering Messiah Paradox in the Gospel of Matthew
}

\author{
SARAH Gagliano \\ $4^{\text {th }}$ Year, Honours BSc \\ University of Toronto \\ Toronto, Ontario
}

\begin{abstract}
A Messiah who must suffer would have been a paradox for the Jewish people of the first century. However, in the Gospel of Matthew, even though the author notes that Jesus Christ is in fact the promised and awaited liberator of the Jewish people, the Messiah must suffer. The author prepares the disciples and his readers to anticipate this paradox by using comparisons between Jesus Christ and other characters who also suffer and by including explicit predictions of the suffering of Jesus. At the same time, the opportunity to doubt this phenomenon is permitted.
\end{abstract}

The Hebrew term "Messiah" refers to an anointed person. ${ }^{1}$ In light of the Hebrew Bible, this term was associated with a variety of figures including a redeemer, a priest, a warrior, and a royal figure. ${ }^{2}$ In the context of the royal figure, prophecies in the Hebrew Scriptures spoke of a future ideal ruler who would be a descendent of David, but unlike any other historical king. Through this ruler God would bring about lasting changes, including a new era marked by peace, the reunification of Israel and Judah, the return of the exiles and world-wide salvation. ${ }^{3}$

Throughout the Gospel of Matthew, the author identifies that for the disciples, Jesus is the promised Messiah sent by God to restore Israel. ${ }^{4}$ At the very beginning of the Gospel, the opening genealogy attests to Jesus' Davidic ancestry, and thus agrees with the description of the Messiah implied in the prophecies of the Hebrew Scriptures. Then at Caesarea Philippi, Peter

\footnotetext{
${ }^{1}$ David Noel Freedman, "Messiah," in The Anchor Bible Dictionary Vol 4., ed.David Noel Freedman (New York: Doubleday, 1992), 777.

${ }^{2}$ Ibid., 787.

${ }^{3}$ Ibid., 781 .

${ }^{4}$ Donald Senior, Matthew (Nashville: Abingdon Press, 1998), 27.
} 
explicitly acknowledges Jesus' identity: "You are the Messiah, the Son of the living God" (16:16 NRSV). However, as the Gospel unfolds, through the events of the Passion (26:1-27:56), Peter and the other disciples witness their Messiah's betrayal, suffering, and death. A suffering Messiah would have been the opposite of commonplace for the Jewish people at the time of Jesus. ${ }^{5}$ As a consequence, the events of the Passion seem to challenge the disciples' expectations of the Messiah. Despite the prior strong affirmations regarding Jesus' identity as the expected Messiah, the concept of a suffering Messiah is nevertheless presented by the author as difficult to accept for the disciples. For instance, when Jesus is faced with suffering, the disciples abandon him by literally fleeing (26:56) and also, as in the case of Peter, through denial (26:69-75).

The author of the Gospel of Matthew provides adequate preparation to the readers for the unexpected: the paradox of a suffering Messiah. He accomplishes this task through the consistent use of appeals to associate Jesus with two characters that also experience suffering: John the Baptist and the protagonist of the servant poems in Isaiah. The author also achieves this purpose through the explicit predictions of suffering. Despite this preparation, Matthew acknowledges that the readers, similar to the disciples, may still have difficulty accepting the paradox.

First of all, in order to prepare the readers for the Passion of the Messiah, Matthew compares Jesus to John the Baptist. Dale Allison calls this technique of relating one character to another "implicit parallelism.." By means of this continual association, Matthew implicitly suggests that another similarity between Jesus and John will be a fate of suffering and death. He accomplishes this parallelism by introducing John as Jesus' forerunner, by having Jesus use phrases that were previously said by John, and by presenting the people as having similar views and reactions to both Jesus and John. To begin with, John is presented as the forerunner of Jesus.

\footnotetext{
${ }^{5}$ Floyd V. Filson, Harper's New Testament Commentaries: The Gospel According to St. Matthew (New York: Harper \& Brothers, 1960), 188.

${ }^{6}$ Dale Allison, The New Moses: A Matthean Typology (Minneapolis: Fortress Press, 1998), 137.
} 
He is the one who cried out, "Prepare the way of the Lord" (3:3), and in doing so announced the coming of Jesus. ${ }^{7}$ The one who is to come is thus expected to have the same fate as the messenger. Furthermore, several phrases coined by John are subsequently used by Jesus, including the expression, "Repent, for the kingdom of heaven has come near." This phrase is first stated by John (3:2), and then by Jesus (4:17). In addition, John calls the Pharisees, "You brood of vipers" (3:7). These same words are later used by Jesus to refer to the Pharisees (12:34). Finally, the people have similar views with regard to John and Jesus. Both John (14:5) and Jesus (21:11) are regarded by "the crowds" as prophets. They are also both rejected by "this generation" since John is accused of having "a demon" (11:18) and Jesus is seen as "a glutton and drunkard" (11:19). Consequently, Matthew prepares the readers to expect that the fate of John will be the fate of Jesus. John is arrested and bound (14:3), and is executed by Herod (14:611). Thus, it should not be a surprise to read that Jesus too will be arrested (26:50), bound (27:2) and sent to death by Pilate (27:26). Through implicit parallelism, Matthew prepares the readers for the idea that the disciples' Messiah, similar to John the Baptist, must suffer.

Secondly, Matthew prepares the readers for the suffering of the Messiah by associating Jesus with the protagonist of the servant poems found in Isaiah. In doing so he identifies Jesus' ministry with the ministry of the servant, which includes suffering. ${ }^{8}$ Matthew establishes this connection by incorporating fulfillment quotations as well as more implicit comparisons that relate Jesus to the servant throughout the gospel.

An example of such a fulfillment quotation is included in the context of Jesus' healing mission. Matthew writes, “This is to fulfill what had been spoken through the prophet Isaiah, 'He

\footnotetext{
${ }^{7}$ Filson, 138.

${ }^{8}$ Allison, 234.
} 
took our infirmities and bore our diseases"” (8:17). This citation is taken from Isaiah 53:4, which is a line from the final servant poem. In addition to fulfillment quotations, Matthew also includes more subtle suggestions that encourage the readers to equate Jesus to the servant. In the description of the Last Supper, the author of Matthew uniquely includes that the cup of the blood is poured out "for many for the forgiveness of sins" (26:28). Warren Carter notes that the inclusion of the term "many" invokes several scriptural passages, including the servant poems in Isaiah, since in the final poem, the righteous servant suffers on behalf of others to make "many" righteous (Isa 53:11).$^{9}$ Furthermore, Jesus' silence when questioned by the high priest (26:63) and later by Pilate (27:14) reflects the servant's silence when he was "oppressed" and "afflicted" (Isa 53:7). ${ }^{10}$ The recurrent connections made between Jesus and a servant who encounters suffering prepare readers to expect that, contrary to the Jewish views of a Messiah who triumphs quickly, Jesus must first suffer.

By associating Jesus with the protagonist of the servant poems in Isaiah, Matthew also offers hope to the readers who, despite the preparation, cannot come to accept the idea of a suffering Messiah. The recurring association suggests that suffering will not mark the end of Jesus' story, just as it did not conclude the servant's mission. It is only after suffering that the servant in Isaiah's poems restores and brings salvation for the people: "But he was wounded for our transgressions, crushed for our iniquities; upon him was the punishment that made us whole, and by his bruises we are healed" (Isa 53:5). Thus, it is to be expected that Jesus' mission will not end with suffering and death. Through the resurrection, the suffering of Jesus, as does the servant's, restores. As Jesus explains to the disciples at the Last Supper, his suffering is necessary

\footnotetext{
${ }^{9}$ Warren Carter, Matthew: Storyteller, Interpreter, Evangelist, Rev. ed. (Peabody: Hendrickson, 2004), 193.

${ }^{10}$ Senior, 312 \& 320
} 
to constitute a new covenant for "the forgiveness of sins" (26:28). This covenant ultimately manifests as a future eternal salvation for those who believe in him.

Finally, Matthew prepares the readers to expect Jesus' suffering through a crescendo of explicit predictions of the Passion, but he simultaneously accepts that doubts may persist. On three separate occasions, Jesus predicts his death and resurrection. The first prediction (16:21-23) is the most subtle because it is written in the third person. It is included in the text immediately following Peter's confession at Caesarea Philippi. This strategic placement makes the paradox clear because immediately following Peter's affirmation that Jesus is the Messiah, Jesus challenges the traditional views of the Messiah by saying that suffering is imminent. Faced with this paradox, Peter rebukes Jesus (16:22), which gives the impression that he and the other disciples understand the term Messiah in a way that does not yet include God's understanding. The disciples' doubt assures the readers that it is acceptable to encounter difficulties coming to terms with the idea that the Messiah must suffer. Consequently, this prediction confirms that suffering will be part of the Messiah's life, and it simultaneously addresses the difficulty of accepting this paradox.

The other two predictions also accomplish this task. Matthew makes the second prediction more direct by quoting Jesus. Again, the disciples cannot accept Jesus' prediction since they are described by the author of Matthew as being "greatly distressed" (17:23). The third prediction is the most direct. Similar to the second, the final prediction is a direct quote from Jesus. In comparison to the previous predictions, the third provides a more elaborate description: "See, we are going up to Jerusalem, and the Son of Man will be handed over to the chief priests and scribes, and they will condemn him to death; then they will hand him over to the Gentiles to be mocked and flogged and crucified; and on the third day he will be raised" 
(20:18-19). Matthew's implicit and explicit clues that the Messiah will suffer, combined with the disciples' lack of acceptance, assures the readers that although difficult to accept, suffering will be a part of Jesus' life. Importantly, in addition to suffering, the resurrection is also explicitly predicted by Jesus. Similar to the association of Jesus with the protagonist of the servant poems, this inclusion suggests that the narrative will not conclude with suffering, and thus neither does Jesus' mission.

The author of the Gospel of Matthew conquers the paradox of a suffering Messiah by incorporating literary techniques including the use of implicit parallelism to associate Jesus with characters who ultimately encounter suffering, and the use of explicit foreshadowing. Through these methods this author has effectively exploited the art of the written story. As a consequence, the study of this gospel is not solely beneficial for believers, but those interested in studying the use of techniques to effectively bring about messages in a narrative will also gain from reading this text. 


\section{Bibliography}

Allison, Dale. The New Moses: A Matthean Typology. Minneapolis: Fortress Press, 1998.

Carter, Warren. Matthew: Storyteller, Interpreter, Evangelist. Revised edition. Peabody: Hendrickson, 2004.

Filson, Floyd V. Harper's New Testament Commentaries: The Gospel According to St. Matthew. New York: Harper \& Brothers, 1960.

Freedman, David Noel. "Messiah" in The Anchor Bible Dictionary, Vol 4., edited by David Noel Freedman. New York: Doubleday, 1992.

Holy Bible: New Revised Standard Version with Apocrypha. New York: Hendrickson Publishers, 2011.

Senior, Donald. Matthew. Nashville: Abingdon Press, 1998. 